\title{
INVESTIGATION OF FABRIC WASTAGES IN KNIT T-SHIRT MANUFACTURING INDUSTRY IN BANGLADESH
}

\author{
Md. Mominur Rahman ${ }^{1}$, Md. Mahbubul Haque ${ }^{2}$ \\ ${ }^{1}$ Department of Textile Engineering, Daffodil International University, 102 Sukrabad, Mirpur Road, Dhaka-1207, \\ Bangladesh \\ ${ }^{2}$ Department of Textile Engineering, Daffodil International University, 102 Sukrabad, Mirpur Road, Dhaka-1207, \\ Bangladesh
}

\begin{abstract}
This work reported here is the investigation of fabric wastages in different sections of a knit T-shirt manufacturing industry. Fabric wastage of different styles and sizes of knit T-shirt occurred in different stages of manufacturing e.g. cutting, panel checking, sewing and finishing were recorded and expressed as percentage of original fabric weight. It was observed that on average more than $26.50 \%$ waste is generated at various stages of which $13.57 \%$ wastage is unavoidable in cutting section, $6.91 \%$ is wasted in panel checking, $4.31 \%$ is wasted in sewing section and $1.72 \%$ is wasted in the finishing section.
\end{abstract}

Keywords: Fabric Wastage, Cutting, Panel Checking, Sewing, Finishing.

\section{INTRODUCTION}

For every garments industry productivity and wastage reduction is one of the most important factors besides quality, workers' efficiency, working environment to sustain in competitive market. Now it is time to concentrate on this matter to reduce not only lead time but also to meet right manufacturing cost followed by the reduction of fabric wastage. Because around $70-80 \%$ of the total garments cost is associated with fabric cost. Garments industry emits a wide variety of fabric wastages from all stages in the processing i.e. in sampling, cutting, sewing and finishing section. Apart from this, it is very important to investigate the fabric wastages percentage and causes of reducing fabric wastages which will result in not only avoid the losses, but also increase the profit level of companies.

There are different sections of a garment industry like sample, cutting, sewing and finishing section, where for different cause's fabric wastages are happened. During cutting there are two different fabric wastages like one for marker efficiency and another for panel checking followed by different types of fabric faults. Apart from this, a garment industry in Thailand shows that waste is generated in cutting, sewing and in the process of quality control [1].Whereas, reduction of fabric wastage results the reduction of production costs [2]. Again, a study shows cutting process counts for $16.36 \%$ of waste from the total material intake to produce 100 t-shirts and $6.37 \%$ of waste was left over from sewing and $0.09 \%$ from quality control [1]. In marker, proper cut plan according to marker results lower fabric consumptions and lower product's cost [3]. Every day average 9 pieces of garments are rejected in every sewing line [4]. So, waste management has essentially become very important in garments industry. Proper production planning and control can easily reduce waste in garments industry which resulting in increment of economy of the industry [5]. So, to reduce the fabric wastages lean production system [6] and value stream mapping is very efficient and effective [7].

Research regarding this shows there are different techniques like lean, kanban, value stream mapping, cut order plan, efficient marker making is used to minimize the fabric wastage in garments industry. Again there are some case studies on cutting and sewing section including the causes of wastages of different countries as well as on some defects, alter and rejection analysis for reducing the wastages. But there is no clear indication about amount of fabric wastage and efficiency. This paper is a framework for those areas.

\section{MATERIALS AND METHODS}

This study was conducted in a garments (T-shirt) industry of Bangladesh. The fabric wastages in various stages of bulk production e.g. in cutting section (bulk cutting \& panel checking), sewing and finishing section were recorded and then expressed as percentage of original weight knit fabric taken out from the store. The detail procedure is again elaborated as follow;

\subsection{Cutting Section}

In the cutting section there are two different activities e.g. bulk cutting and panel checking. After bulk cutting, the fabric waste\% was found out by deducting marker efficiency from 100. The three information i.e. original fabric weight, taken out from the store, weight of wastage and wastage $\%$ is shown in the $2^{\text {nd }}, 3^{\text {rd }}$ and last column of table 1. The data were collected in five different days and each time the same information was recorded and wastages $\%$ were calculated. 
Table 1: Fabric Wastage Report in Cutting

\begin{tabular}{|l|l|l|l|}
\hline Day & $\begin{array}{l}\text { Total Taken } \\
\text { Fabric Wt. from } \\
\text { Store }(\mathrm{gm})\end{array}$ & $\begin{array}{l}\text { Total Wastage } \\
\text { Wt. in Cutting } \\
(\mathrm{gm})\end{array}$ & $\begin{array}{l}\text { Wastage } \\
(\%)\end{array}$ \\
\hline 1 & 16551 & 2731 & 16.50 \\
\hline 2 & 25255 & 3800 & 15.04 \\
\hline 3 & 27541 & 3811 & 13.83 \\
\hline 4 & 27798 & 3047 & 10.96 \\
\hline 5 & 29717 & 3437 & 11.56 \\
\hline Gross & 126862 & 16826 & 13.26 \\
\hline
\end{tabular}

Apart from this, during bulk cutting fabric wastages are caused for not only for marker efficiency but also for different factors like poor marker planning, poor fabric spreading, and wrong placement of marker. The image of fabric wastages caused for cutting mistake is shown in Figure 1.

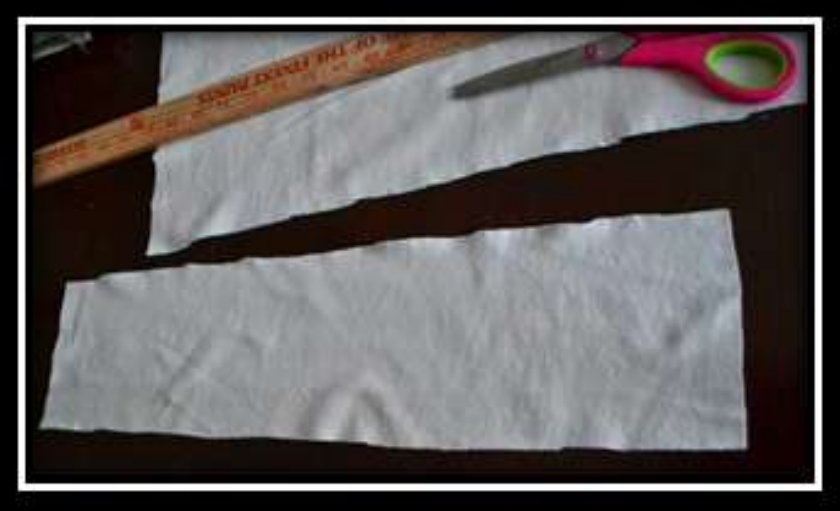

Fig 1: Cutting Mistake

\subsection{Panel Checking}

This is carried out to find out the defective garments parts. The defective parts are rejected. Once identified the defective parts were weighed and expressed as percentage of original fabric weight shown in column 2 of table-1. The original fabric weight, the weight of rejected cut panels and waste percentages are shown in the second, third and last column of table -2. Like table1, the wastages were calculated for 5 days and are shown in Table 2.

Table 2: Fabric Wastage Report in Panel Checking

\begin{tabular}{|l|l|l|l|}
\hline Day & $\begin{array}{l}\text { Total Taken } \\
\text { Fabric Wt. } \\
\text { from Store } \\
(\mathrm{gm})\end{array}$ & $\begin{array}{l}\text { Total } \\
\text { Wastage in } \\
\text { Panel Checking } \\
(\mathrm{gm})\end{array}$ & $\begin{array}{l}\text { Wastage } \\
(\%)\end{array}$ \\
\hline 1 & 16551 & 1104.6 & 6.67 \\
\hline 2 & 25255 & 1714.4 & 6.78 \\
\hline 3 & 27541 & 1902.4 & 6.90 \\
\hline 4 & 27798 & 1980.08 & 7.12 \\
\hline 5 & 29717 & 2109.4 & 7.09 \\
\hline Gross & 126862 & 8810.88 & 6.94 \\
\hline
\end{tabular}

Apart from this, fabric wastages are found in panel checking mainly for defective fabric, unskilled cutter man, faulty equipment and cut fabric for different activities like GSM test, shrinkage test, lab dip purpose etc. which is supplied from dyeing and finishing section. Sometimes wastages are happened for faulty printing and embroidery in different garments parts. And the variation of wastages, efficiencies in different days and also for different references is for the variation of mentioned factors. The image of some faults for fabric wastages in sewing section are shown in Figure 2.

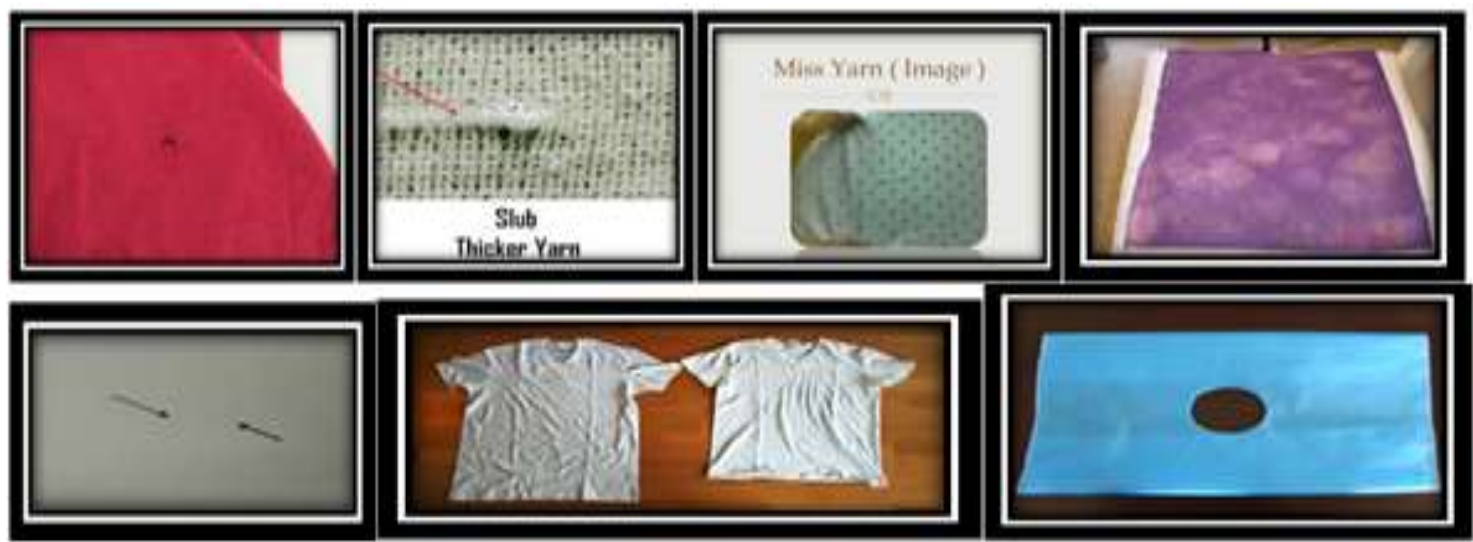

Fig 2: Hole, Thick Yarn, Miss Yarn, Dyeing Spot, Thick and Thin Place, Shrinkage Problem, GSM Cut.

\subsection{Sewing Section}

In sewing section fabric wastage data was calculated by identifying the rejected T-shirts. The fabric weight of each T-shirt was calculated from the fabric consumption formula. In this way weight of all the rejected garments were added together and expressed as percentage of original fabric weight shown in the second column of table 1 . Original fabric weight and corresponding waste $\%$ are shown in table -3 .
Table 3: Fabric Wastage Report in Sewing

\begin{tabular}{|l|l|l|l|}
\hline Day & $\begin{array}{l}\text { Total Taken } \\
\text { Fabric Wt. from } \\
\text { Store }(\mathrm{gm})\end{array}$ & $\begin{array}{l}\text { Total } \\
\text { Wastage in } \\
\text { Sewing }(\mathrm{gm})\end{array}$ & $\begin{array}{l}\text { Wastage } \\
(\%)\end{array}$ \\
\hline 1 & 16551 & 687 & 4.15 \\
\hline 2 & 25255 & 1072.75 & 4.24 \\
\hline 3 & 27541 & 1182.5 & 4.29 \\
\hline 4 & 27798 & 1239.55 & 4.45 \\
\hline 5 & 29717 & 1314 & 4.42 \\
\hline Gross & 126862 & 5495.8 & 4.33 \\
\hline
\end{tabular}


Apart from this, in sewing section fabric wastages are caused by garments rejection due to different types of sewing faults which are caused for unskilled operators and faulty sewing machines. The image of some faults for fabric wastages in sewing section are shown in Figure 3.
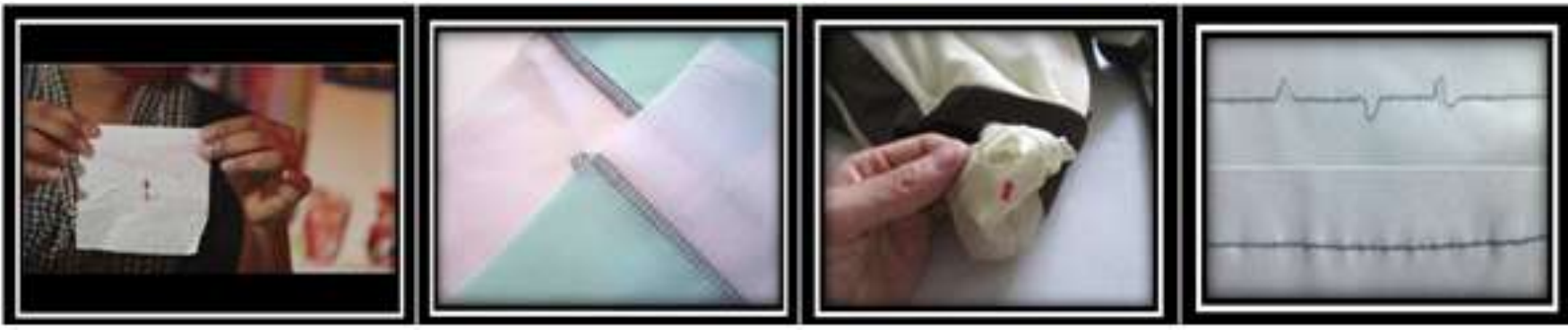

Fig 3: Sewing Needle Cut, Fabric Join Defect, Sewing Machine Defects.

\subsection{Finishing Section}

Similar to calculation of sewing waste, the waste in the finishing section was found out by identifying the rejected garments. After that fabric weight was calculated from the fabric consumption formula. The fabric weight was then expressed as percentage of original fabric weight shown in the $2^{\text {nd }}$ column of table 1 . The original fabric weight, waste in the finishing section and waste percentage is shown in $2^{\text {nd }}, 3^{\text {rd }}$ and last column of table 4 . Like previous tables the waste percentage of five days were also calculated and shown in the table 4.
Table 4: Fabric Wastage Report in Finishing

\begin{tabular}{|l|lr|l|l|}
\hline Day & $\begin{array}{l}\text { Total } \\
\text { Fabric } \\
\text { from } \\
(\mathrm{gm})\end{array}$ & $\begin{array}{r}\text { Taken } \\
\text { Wt. }\end{array}$ & $\begin{array}{l}\text { Total } \\
\text { Wastage in } \\
\text { Finishing } \\
(\mathrm{gm})\end{array}$ & $\begin{array}{l}\text { Wastage } \\
(\%)\end{array}$ \\
\hline 1 & 16551 & 276.4 & 1.66 \\
\hline 2 & 25255 & 429.1 & 1.69 \\
\hline 3 & 27541 & 474.6 & 1.72 \\
\hline 4 & 27798 & 495.02 & 1.78 \\
\hline 5 & 29717 & 525.6 & 1.76 \\
\hline Gross & 126862 & 2200.72 & 1.73 \\
\hline
\end{tabular}

Apart from this in finsihing section, wastages are characterized for different types of faults incorporated in finishing section, heavy spot, problems in ironing and measuring which are caused for improper guideline for garments manufacturing. The image of some faults for fabric wastages are shown in Figure 4.
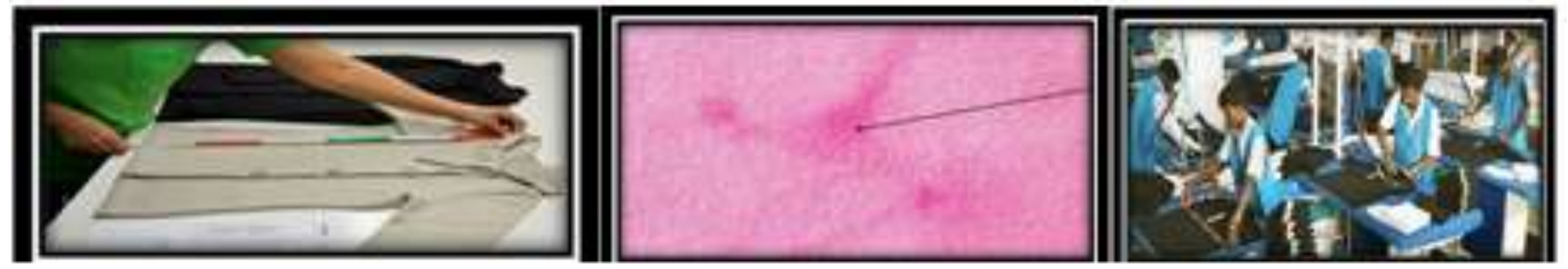

Fig 4: Measuring, Heavy Spots, Ironing Defects.

Thus four types of wastages were identified and recorded. For better understanding all these wastages are presented in summarized form in table-5.

Table 5: Summary of Fabric Wastages in Different Sections

\begin{tabular}{|c|c|c|c|c|c|c|}
\hline \multirow[t]{2}{*}{ Day } & \multirow{2}{*}{$\begin{array}{lr}\text { Total } & \text { Taken } \\
\text { Fabric } & \text { Wt. } \\
\text { from } & \text { Store } \\
(\mathrm{gm}) & \end{array}$} & \multicolumn{4}{|c|}{ Fabric Wastage \% in } & \multirow{2}{*}{$\begin{array}{l}\text { Total } \\
\text { Wastage } \\
(\%)\end{array}$} \\
\hline & & Cutting & $\begin{array}{l}\text { Panel } \\
\text { Checking }\end{array}$ & Sewing & Finishing & \\
\hline 1 & 16551 & 16.50 & 6.67 & 4.15 & 1.66 & 28.98 \\
\hline 2 & 25255 & 15.04 & 6.78 & 4.24 & 1.69 & 27.75 \\
\hline 3 & 27541 & 13.83 & 6.90 & 4.29 & 1.72 & 26.74 \\
\hline 4 & 27798 & 10.96 & 7.12 & 4.45 & 1.78 & 24.31 \\
\hline 5 & 29717 & 11.56 & 7.09 & 4.42 & 1.76 & 24.83 \\
\hline Average & 25372.4 & 13.57 & 6.91 & 4.31 & 1.72 & 26.52 \\
\hline
\end{tabular}




\section{DISCUSSION OF RESULTS}

\subsection{Cutting Section}

It was observed from Table 1, during bulk cutting there is gross fabric wastages of $13.26 \%$ and average wastage is of $13.57 \%$ (Table 5). The table also shows that wastage percentage varies significantly from day to day. The wastage was calculated from the marker efficiency which varied due to variation of marker size, marker number, marker ratio etc. from day to day.

\subsection{Panel Checking}

Table 2 and 5 shows that on average $6.91 \%$ fabric is wasted in panel checking. This waste occurs due to identification and rejection of faulty pattern pieces. This waste absolutely depends on the fabric faults. Off course fabric rolls are inspected once before cutting even then wastes are being occurs. Therefore by reducing fabric defects it will be possible to reduce waste $\%$ in panel checking.

\subsection{Sewing Section}

Table 3 and 5 shows that on average $4.31 \%$ fabric is wasted in sewing section. This waste is actually rejected garments. There are mainly two types sewing defects for which garments are rejected e.g. defect related unskilled operator and defects related to out of order machine. Both the factor can lead to a faulty garments and need to be addressed properly. Generally new and well maintained machines will give less machine related faults in the garments while experienced operator expected to produce lower number of defective garments. However it may be a matter of interest to study the causes of garment rejection in sewing section.

\subsection{Finishing Section}

It is observed in Table $4 \& 5$ that $1.72 \%$ fabric is wasted in the finishing section. Though, the waste percentage is small but not insignificant. In finishing section fabric wastages are occurred mainly for heavy spot, ironing, measuring problems. Careful and experienced operators can reduce this types waste to a great extent.

\section{CONCLUSION}

Significant amount (26.52\%) of materail is wasted during Tshirt manufacturing. Roughly half of total waste is ocurred in cutting section which happens in CAD/CAM system and somewhat unavoidable but it will vary depending on the style, size etc.. Rest of the wastes are produced in the subsequent section and can be controlled to a great extent by employing (i) experienced and well educated operator; (ii) well maintained machines; and (iii) better supervision.

\section{REFERENCES}

[1]. Kasemset, Chompoonoot, (2015), Jintana Chernsupornchai; Wannisa Pala-ud. Application of MFCA in waste reduction: case study on a small textile factory in Thailand. Journal of Cleaner Production 108, pp. 1342-1351.
[2]. Wong. W, Leung. S.Y. S. A. (2009), Hybrid Planning for Improving Fabric Utilization. Textile Research Journal, vol. 79 no. 18 1680-1695.

[3]. E. Dumishllari , G. Guxho, (2015), Impact of Marker on Cut Plan in Garment Production, International Journal of Innovative Research in Science, Engineering and Technology, Vol. 4, Issue 8, ISSN(Online): 2319-8753, ISSN (Print): 2347-6710.

[4]. R. Karim, C.M.L. Rahman, (2012), Application of Lean Manufacturing Tools for Performance Analysis: A Case Study, Proceedings of the 2012 International Conference on Industrial Engineering and Operations Management Istanbul, Turkey, July $3-6$.

[5]. Dr.J.Senthil Velmurugan, B.G.Ramaraj, (2014), A BIRD VIEW OF WASTE MANAGEMENT IN GARMENT INDUSTRY SPECIAL REFERENCE TO TIRUPUR DISTRICT, Asia Pacific Journal of Research, Vol: I Issue XI, ISSN: 2320-5504, E-ISSN-2347-4793 Page 169.

[6]. S. Mazumder, (2015), Lean Wastes and its Consequences for Readymade Garments Manufacturing, Global Journal of Researches in Engineering: Industrial Engineering, Volume 15 Issue 1 Version 1.0, Online ISSN: 2249-4596 \& Print ISSN: 0975-5861.

[7]. Silva S.K. N. (2012), Applicability of Value Stream Mapping (VSM) in the Apparel industry in Sri Lanka , International Journal of Lean Thinking, Volume 3, Issue 1. 